\title{
Effect of Different Nitrogen Level and Rice Straw Incorporation on the Productivity of Barley (Hordeum vulgare L.) in South-West Punjab
}

\author{
Ramneet Singh, Balwinder Singh Dhillon* and Sham Singh Dhillon
}

College of Agriculture, Guru Kashi University, Talwandi Sabo, Punjab, India

*Corresponding author

\begin{abstract}
A B S T R A C T

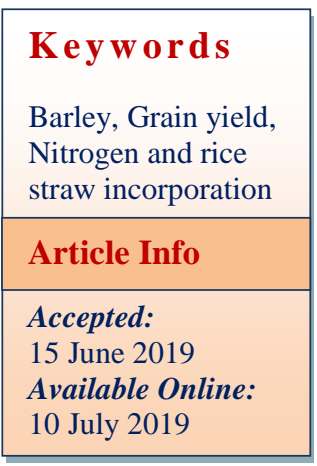

The field experiment entitled Effect of different nitrogen levels and rice straw incorporation on growth and Productivity of Barley (Hordeum vulgare L.) in south-west Punjab was conducted during the rabi season of 2017-18 at Research Farm of Guru Kashi University, Talwandi Sabo, Bathinda (Punjab). The trail was laid out in split plot design with four nitrogen levels viz., $0 \mathrm{~kg} \mathrm{~N} / \mathrm{ha}\left(\mathrm{N}_{0}\right), 40 \mathrm{~kg} \mathrm{~N} / \mathrm{ha}\left(\mathrm{N}_{1}\right), 60 \mathrm{~kg} \mathrm{~N} / \mathrm{ha}\left(\mathrm{N}_{2}\right)$ and $80 \mathrm{~kg}$ $\mathrm{N} / \mathrm{ha}\left(\mathrm{N}_{3}\right)$ in main plot and two levels of rice straw incorporation viz., Control $\left(\mathrm{S}_{0}\right)$ and 10 tonnes/ha $\left(\mathrm{S}_{1}\right)$ in sub plot. The results showed that the $80 \mathrm{~kg} \mathrm{~N} / \mathrm{ha}$ recorded maximum plant height $(88.9 \mathrm{~cm})$, dry matter accumulation (107.4 q/ha), number of effective tillers $/ \mathrm{m}^{2}(275.1)$, ear length $(17.9 \mathrm{~cm})$, number of grains per ear $(59.8)$ and test weight $(50.4 \mathrm{~g})$, grain yield $(40.7 \mathrm{q} / \mathrm{ha})$, straw yield $(75.6 \mathrm{q} / \mathrm{ha})$ and harvest index $(35.00 \%)$ than other nitrogen levels. Similarly, application of rice straw incorporation@10 tonnes/ha recorded higher plant height $(85.4 \mathrm{~cm})$, dry matter accumulation $\left(98.1 \mathrm{q} \mathrm{ha}^{-1}\right)$ and yield attributes i.e. number of effective tillers $/ \mathrm{m}^{2}$ (263.8), ear length $(18.0 \mathrm{~cm})$, number of grains/ear (57.9) and test weight (50.8 g) as compared to control.
\end{abstract}

\section{Introduction}

Barley (Hordeum vulgare L.) is an ancient and major cereal grown in temperate climate, globally. It is the fourth largest cereal in the world with $7 \%$ of total cereal production. This crop requires temperature of $12^{\circ} \mathrm{C}$ to $16^{\circ} \mathrm{C}$ at growing stage and about $30^{\circ} \mathrm{C}$ to $32^{\circ} \mathrm{C}$ at maturity. It is considered as poor man's crop. Barley is considered as a valuable crop because it is grown for several purposes such as food and processed food products for human being and feed for cattle and poultry birds. Barley grain is also valued for smothering and cooling effect on the body for easy digestion. Barley helps in the prevention of gallstones in women, thus helps in improving the immunity system. It is highly beneficial for the anemia tic patients, prevents cancer, diabetes, and makes bones stronger. Besides these conventional uses, it is an important industrial crop as it is used as raw material for beer, whisky and brewing Barley. The small and marginal farmers of Rajasthan cut the green barley and feed it to farm and mulch animals. Each $100 \mathrm{~g}$ of barley grain comprise $10.6 \mathrm{~g}$ protein, $2.1 \mathrm{~g}$ fat, $64 \mathrm{~g}$ carbohydrate, $50 \mathrm{mg}$ calcium. In recent past, 
India has made an impressive progress in achieving self sufficiency in food grain production by elevating productivity of several crops but the breakthrough has not been achieved in barley. Besides other factors, nutritional supply may be crucial for successful as well as profitable cultivation of barley.

Nitrogen (N) is the main constituent of chlorophyll and amino acids which are precursor to protein. Malt barley's grain yield, grain protein and kernel plumpness are characteristics strongly related to available nitrogen (Grant, 2000). Lauer and partridge (1990) observed that grain yield and protein content increased significantly with increase in $\mathrm{N}$ levels. Insufficient nitrogen can reduce grain yield and quality below acceptable levels. Application of $\mathrm{N}$ significantly increased the yield from $22.5 \mathrm{q} / \mathrm{ha}$ with $60 \mathrm{~kg}$ $\mathrm{N} / \mathrm{ha}$ to $29.3 \mathrm{q} / \mathrm{ha}$. However, $80 \mathrm{~kg} \mathrm{~N} / \mathrm{ha}$ usually produces undesirable high protein level (Yadav et al., 2003). Straw mulch also provides benefit in terms of increasing maintains the optimum temperature, improves fertilizer availability and increase the crop yield (Dushouyu et al., 1995). The intensive and continuum use of rice-wheat rotation in Punjab leads to excessive use of irrigation water and soil health problems. The problems of handing the rice straw can be solved by incorporate the straw by cutter cum spreader, disc harrow and rotavator etc. Barley offers a good scope for crop diversification. Keeping in view the present study was planned to study the effect of different levels of nitrogen and rice straw incorporation on the performance of barley.

\section{Materials and Methods}

A field experiment "Effect of different nitrogen level and rice straw incorporation on the productivity of barley" was conducted at Research Farm, College of Agriculture, Guru
Kashi University, Talwandi Sabo, Bathinda during rabi season 2017-18. Talwandi Sabo is located at $29^{\circ} 57 \mathrm{~N}$ latitude and $75^{\circ} 7 \mathrm{E}$ longitudes and altitude $(213 \mathrm{~m}$ above sea level). The tract is characterized by semi humid climate. The mean annual rainfall fluctuates around $150 \mathrm{~mm}$, major part of which is during the month of July to November with a few shower of cyclonic rains during winter and spring month.

The soil was alkaline $(\mathrm{pH} 8.2)$ with normal electrical conductivity $\left(0.34 \mathrm{dSm}^{-1}\right)$. The soil was low in both organic carbon content $(0.32 \%)$ and $\mathrm{CaCO}_{3}$ content (2.5\%). The available nitrogen (125 kg/ha) was low, whereas the available phosphorus (13.9 $\mathrm{kg} / \mathrm{ha})$ and available potash $(245.6 \mathrm{~kg} / \mathrm{ha})$ were both medium. The experiment was laid out in split plot design with three replications. The treatments comprised of four level of nitrogen $(0,40,60$ and $80 \mathrm{~kg} / \mathrm{ha})$ and two rice straw incorporation (no straw and 10 tones/ha).

The height of five randomly selected plants was measured at maturity. Tillers bearing panicles were counted and recorded as productive tillers. The observations were taken differently from every five randomly selected plants from each plot. The number of ear grains per ear counted from the best ears of the selected plants. Dry matter accumulation was recorded from each plot. The plant biomass harvested from individual plots was first sun dried followed by oven drying at $65^{\circ} \mathrm{C}$ till constant weight was obtained. After complete drying, dry weight at 120 days after sowing (DAS) was recorded and converted into $\mathrm{g} / \mathrm{m}^{2}$. The samples of 1000-grains were drawn from each plot after cleaning mean value was worked out after recording their weight. The weight of total production from the net plot was recorded after harvest with help of electronic balance. The weight of the grain per net plot was 
record in kilogram after threshing of the produce. Later on it was converted into grain yield (q/ha). The straw yield was worked out from the weight of total biomass and expressed as $\mathrm{q} / \mathrm{ha}$. The biological yield was calculated by the addition of grain yield and straw yield. Harvest index (HI) was calculated by using following formula;

Harvest Index $(\%)=\frac{\text { Seed yield }}{\text { Biological yield }} \times 100$

Fisher's ANOVA technique and least significant difference (LSD) test at 5\% probability level was used to compare differences among treatment means (Steel et al., 1997).

\section{Results and Discussion}

\section{Growth parameters of barley}

The highest plant height was recorded in 80 $\mathrm{kg} \mathrm{N} /$ ha treatment than other nitrogen levels i.e. 0,40 and $60 \mathrm{~kg} \mathrm{~N} / \mathrm{ha}$ (Table 1). Among the rice straw incorporation, maximum plant height was observed in rice straw incorporation@10 t/ha than control. Among N levels, $80 \mathrm{~kg} \mathrm{~N} / \mathrm{ha}$ recorded significantly higher dry matter accumulation than other nitrogen treatments, while minimum dry matter accumulation was obtained in control. Nitrogen applied @80 kg/ha with rice straw incorporation $(10 \mathrm{t} / \mathrm{ha})$ resulted in significantly higher dry matter accumulation than other treatment combinations. Similar results were also reported by Alam et al., (2005), Chandra et al., (2015), Mohammadi and Farideh (2014), Awasthi and Suraj Bhan (1993), Prokhorov et al., (1998) and Nagarajan and Wahab (2001).

\section{Yield attributes of barley}

The ear length of barley was highest in N @ $80 \mathrm{~kg} / \mathrm{ha}$ treatment which was significantly higher than other nitrogen levels i.e. 0, 40 and
$60 \mathrm{~kg} / \mathrm{ha}$ (Table 2). Rice straw incorporation (10 tonnes/ha) recorded significantly higher ear length than control. The number of effective tillers $/ \mathrm{m}^{2}$ of barley in $80 \mathrm{~kg} \mathrm{~N} / \mathrm{ha}$ treatments was significantly higher than other nitrogen levels. Rice straw incorporation recorded the maximum effective tillers was than control. Nitrogen applied @ 80 kg/ha with $10 \mathrm{t} / \mathrm{ha}$ rice straw incorporation recorded significantly higher number of effective tiller/ $\mathrm{m}^{2}$ than other treatments. The variation in the above mentioned growth parameters have also been reported by many research workers Shafi et al., (2011), Singh et al., (2013),

The data indicated that application of $80 \mathrm{~kg}$ $\mathrm{N} / \mathrm{ha}$ and rice straw incorporation produced maximum number of grains per ear as compared to other treatments. It may be contributed due to higher ear length for optimum grain development and better partitioning of photosynthesis on higher availability of nitrogen per ear. Rice straw incorporation recorded significantly higher number of grains per ear than control. The variation in the above mentioned growth parameters have also been reported by many research workers Dev and Chauhan (2009) Jan et al., (2011).

The data showed a significant effect of different nitrogen levels and rice straw incorporation on 1000-grain weight of barley. Maximum 1000-grain weight of barley was observed in $\mathrm{N} @ 80 \mathrm{~kg} / \mathrm{ha}$ than other nitrogen level i.e. 0,40 and $60 \mathrm{~kg} / \mathrm{ha}$. While rice straw incorporation recorded significantly higher 1000-grain weight than control. Similar results were also reported by Singh et al., (2005).

\section{Yield of barley}

The grain yield increased with increase in nitrogen levels and the maximum grain yield was recorded in $80 \mathrm{~kg} \mathrm{~N} / \mathrm{ha}$ treatment which 
was significantly higher than other nitrogen levels (Table 3). Rice straw incorporation observed maximum grain yield than control. Nitrogen applied @80 kg/ha with 10 tonnes/ha rice straw incorporation resulted in significantly higher grain yield than other treatment combinations. Similar results were also reported by Singh and Singh (2005), Singh et al., (2013) and Shirazi et al., (2014).

Table.1 Effect of different nitrogen level and rice straw incorporation on growth parameters of barley

\begin{tabular}{|c|c|c|}
\hline Treatment & $\begin{array}{l}\text { Plant height } \\
\text { (cm) }\end{array}$ & $\begin{array}{c}\text { Dry matter } \\
\text { accumulation }\left(\mathrm{q} \mathrm{ha}^{-1}\right)\end{array}$ \\
\hline \multicolumn{3}{|l|}{ Nitrogen levels (kg/ha) } \\
\hline $\mathbf{0}$ & 75.8 & 87.6 \\
\hline 40 & 82.1 & 96.7 \\
\hline 60 & 85.1 & 101.5 \\
\hline 80 & 88.9 & 107.4 \\
\hline LSD (P=0.05) & 1.5 & 0.11 \\
\hline \multicolumn{3}{|l|}{ Rice straw incorporation } \\
\hline Control & 80.5 & 92.1 \\
\hline $\begin{array}{l}\text { Straw incorporation (10 } \\
\text { t/ha) }\end{array}$ & 85.4 & 98.1 \\
\hline LSD (P=0.05) & 2.4 & 0.3 \\
\hline Interaction & 1.8 & 0.2 \\
\hline
\end{tabular}

Table.2 Effect of different nitrogen level and rice straw incorporation on yield attributes of barley

\begin{tabular}{|c|c|c|c|c|}
\hline Treatment & $\begin{array}{l}\text { No. of effective } \\
\text { tillers } / \mathrm{m}^{2}\end{array}$ & $\begin{array}{l}\text { Ear length } \\
\text { (cm) }\end{array}$ & $\begin{array}{c}\text { No. of } \\
\text { grains/ear }\end{array}$ & $\begin{array}{c}\text { 1000-grain } \\
\text { weight (g) }\end{array}$ \\
\hline \multicolumn{5}{|c|}{ Nitrogen levels (kg/ha) } \\
\hline $\mathbf{0}$ & 233.8 & 16.2 & 49.7 & 48.1 \\
\hline 40 & 252.0 & 16.9 & 55.2 & 49.3 \\
\hline 60 & 264.1 & 17.5 & 58.4 & 49.7 \\
\hline 80 & 275.1 & 17.9 & 59.8 & 50.4 \\
\hline LSD (P=0.05) & 3.2 & 0.4 & 2.1 & 0.6 \\
\hline \multicolumn{5}{|c|}{ Rice straw incorporation } \\
\hline Control & 248.7 & 16.7 & 53.6 & 48.0 \\
\hline $\begin{array}{l}\text { Straw } \\
\text { incorporatio } \\
\text { n (10 t/ha) }\end{array}$ & 263.8 & 18.0 & 57.9 & 50.8 \\
\hline $\operatorname{LSD}(\mathbf{P}=\mathbf{0 . 0 5})$ & 2.4 & 0.3 & 1.6 & 0.6 \\
\hline Interaction & 2.8 & NS & NS & NS \\
\hline
\end{tabular}


Table.3 Effect of different nitrogen level and rice straw incorporation on productivity of barley

\begin{tabular}{|l|c|c|c|c|}
\hline Treatment & $\begin{array}{c}\text { Grain yield } \\
(\mathbf{q} / \mathbf{h a})\end{array}$ & $\begin{array}{c}\text { Straw yield } \\
(\mathbf{q} / \mathbf{h a})\end{array}$ & $\begin{array}{c}\text { Biological yield } \\
(\mathbf{q} / \mathbf{h a})\end{array}$ & $\begin{array}{c}\text { Harvesting } \\
\text { index (\%) }\end{array}$ \\
\hline Nitrogen levels (kg/ha) & \multicolumn{4}{|c|}{} \\
\hline $\mathbf{0}$ & 31.9 & 68.0 & 99.6 & 31.9 \\
\hline $\mathbf{4 0}$ & 36.5 & 72.4 & 108.9 & 33.5 \\
\hline $\mathbf{6 0}$ & 39.0 & 74.4 & 113.4 & 34.4 \\
\hline $\mathbf{8 0}$ & 40.7 & 75.6 & 116.3 & 35.0 \\
\hline $\mathbf{C D}$ (P=0.05) & 0.9 & 1.3 & 2.9 & 0.4 \\
\hline Rice straw incorporation & & & & \\
\hline $\begin{array}{l}\text { Control } \\
\text { Straw } \\
\text { incorporation (10 } \\
\text { t/ha) }\end{array}$ & 35.7 & 71.5 & 107.3 & 33.2 \\
\hline $\begin{array}{l}\text { LSD (P=0.05) } \\
\text { Interaction }\end{array}$ & 38.3 & 73.7 & 112.0 & 34.1 \\
\hline & 1.2 & & & \\
\hline
\end{tabular}

The highest straw yield was obtained in $80 \mathrm{~kg}$ $\mathrm{N} / \mathrm{ha}$ treatment than other nitrogen levels i.e. 0,40 and $60 \mathrm{~kg} / \mathrm{ha}$. Rice straw incorporation (10 tonnes/ha) recorded significantly higher straw yield than control. Nitrogen applied @ $80 \mathrm{~kg} / \mathrm{ha}$ with 10 tonnes/ha rice straw incorporation resulted in significantly higher straw yield than other treatment combinations. The variation in the above mentioned growth parameters have also been reported by many research workers (Chakrawarthi et al., 2006; Shafi et al., 2011; Jena et al., 2014).

The maximum biological yield was obtained at $80 \mathrm{~kg} \mathrm{~N} / \mathrm{ha}$ than other nitrogen levels. Rice straw incorporation (10 tonnes/ha) obtained significantly higher biological yield than other control. The higher grain yield obtained with more nitrogen application might be attributed to better growth as evident form significantly higher growth attributes i.e. plant height, leaf area index, dry matter accumulation, number of grains per ear, ear length and 1000-grain weight. Rice straw incorporation with $80 \mathrm{~kg}$ $\mathrm{N} / \mathrm{ha}$ recorded significantly higher biological yield than other treatment combinations. The variation in the above mentioned growth parameters have also been reported by many research workers Singh and Singh (2005), Shafi et al., (2011) and Jena et al., (2014). The highest harvest index was found in N @ $80 \mathrm{~kg} / \mathrm{ha}$ than other nitrogen levels. The different rice straw incorporation had significant effect on Harvest index. Rice straw incorporation recorded significantly higher harvest index than control.

In conclusion, application of $80 \mathrm{~kg} \mathrm{~N} / \mathrm{ha}$ gave the maximum grain yield as compared to other $\mathrm{N}$ treatments. $60 \mathrm{~kg} \mathrm{~N} / \mathrm{ha}$ gave at par the $80 \mathrm{~kg} / \mathrm{ha}$. Incorporation of 10 tonnes/ha rice straw resulted in increased the grain yield of barley. Application of $80 \mathrm{~kg} \mathrm{~N} / \mathrm{ha}$ and 10 tonnes/ha rice straw incorporation in produced maximum grain yield of barley.

\section{References}

Alam, M.Z., Haider, S.A. and Paul, N.K. (2007) Yield and yield components of barley (Hordeum vulgare L.) cultivars in relation to nitrogen fertilizer. Journal of Applied Sciences Research 3: 10221026.

Chakrawarti, V.K and Kushwala, K.P. (2006) 
Effect of sowing time, nutrients concentration and uptake on yield maximization of barley (Hordeum vulgare L.). Progressive Agriculture 6: 194-96.

Chandra, P.S., Sharma, P.K. and Sharma, V.K. (2015) Performance of barley (Hordeum vulgare L.) varieties under sowing dates and nitrogen levels. Agriculture Research Journal, 52(1), 89-9

Dev, D. and Chauhan, R.S. (2009). Effect of sowing dates and nitrogen levels on growth and yield of barley (Hordeum vulgare L.). Progressive Agriculture 9: 295-97.

Jan, A., Daur, I., Muhammad, Z. and Khan, I.A. (2011). Effect of mungbean residue and nitrogen levels on barley. Pakistan Journal of Botany 43: 1905-08.

Jena, S., Basu, S., Maji S., Bandyopadhyay, P., Nath, R. and Chakraborthy, P.K. (2014). Effect of nitrogen levels on grain and biological yield of barley. The Ecoscan, 8(3\&4), 279-285.

Mohammadi, A.S. and Farideh, S. (2014). Effect of nitrogen levels on plant height of barley. International journal of Advanced Biological and Biomedical Research, 2, 295-299.

Shafi, M., Bakht, J., Jalal, F., Khan, M.A. and Khattak, S.G. (2011). Effect of nitrogen application on yield and yield component of barley. Pakistan Journal of Botany 43: 1471-75.

Singh, J., Mahal, S.S. and Singh, A. (2013). Yield and quality of barley (Hordeum vulgare L.) as influenced by irrigation, nitrogen and methods of sowing. Indian Journal of Agronomy 58:354-62.

Singh, R.K. and Singh, R.K. (2005). Effect of time and levels of nitrogen application on malt barley (Hordeum vulgare L.). Indian Journal of Agronomy 50: 13739.

Shirazi SM, Zulkifli Y, Zardari NH, Ismail Z. (2014). Effect of irrigation regimes and nitrogen levels on the growth and yield of barley. Advances in Agriculture. 5: 16.

Steel, RGD and Torrie, JH. (1981) Principles and procedures of statistics: A biometrical approach. 2nd Edn. McGraw-Hill, Singapore.

\section{How to cite this article:}

Ramneet Singh, Balwinder Singh Dhillon and Sham Singh Dhillon. 2019. Effect of Different Nitrogen Level and Rice Straw Incorporation on the Productivity of Barley (Hordeum vulgare L.) in South-West Punjab. Int.J.Curr.Microbiol.App.Sci. 8(07): 2010-2015. doi: https://doi.org/10.20546/ijcmas.2019.807.240 